\title{
Zooplankton response to storm runoff in a tropical estuary: bottom-up and top-down controls
}

\author{
R. S. Hoover ${ }^{1,3, * * *}$, D. Hoover ${ }^{1}$, M. Miller ${ }^{1}$, M. R. Landry ${ }^{2}$, E. H. DeCarlo ${ }^{1}$, \\ F. T. Mackenzie ${ }^{1}$ \\ ${ }^{1}$ Department of Oceanography, University of Hawaii at Manoa, Honolulu, Hawaii 96822, USA \\ ${ }^{2}$ Integrative Oceanography Division, Scripps Institution of Oceanography, La Jolla, California 92093-0227, USA
}

${ }^{3}$ Present address: Monterey Bay Aquarium Research Institute, 7700 Sandholdt Road, Moss Landing, California 95039, USA

\begin{abstract}
Zooplankton successional patterns and response times were characterized in a tropical estuary following a major storm-runoff event to evaluate the effects of a nutrient perturbation on community composition and dynamics. Intensive water-column monitoring in southern Kaneohe Bay, Hawaii, showed that dissolved macronutrients $-\mathrm{NO}_{3}{ }^{-}+\mathrm{NO}_{2}{ }^{-}$, $\mathrm{SRP}$ (soluble reactive phosphorus) and $\mathrm{Si}(\mathrm{OH})_{4}$-increased significantly immediately following the initial runoff event. Bottom-up effects were evident in both phytoplankton and zooplankton communities. An initial phytoplankton bloom was dominated by small cells and lasted only a few days, while post-bloom pigment concentrations showed a more gradual increase in total chlorophyll $a$ and a shift to a diatom-dominated community. The initial bloom had an unexpectedly large influence on zooplankton growth and reproduction on extremely short time scales. Appendicularians exhibited the most dramatic response, with biomass increasing 6-fold in $1 \mathrm{~d}$, and abundances reaching values only rarely observed in these waters. Response covaried with organism size, with larger components of the community, especially calanoid copepods and gelatinous zooplankton, increasing as new resources became available. Post-bloom changes in zooplankton and phytoplankton community structure also suggest significant top-down controls on phytoplankton and zooplankton community biomass and structure, with increased predation on appendicularians and copepods resulting in partial release of grazing pressure on small and large cells, respectively. Nutrient-rich runoff can have significant and surprisingly rapid impacts on zooplankton population dynamics in tropical coastal waters via direct, pulsed, food influences on the growth and reproduction of omnivorous organisms and the indirect stimulation of secondary consumers.
\end{abstract}

KEY WORDS: Zooplankton · Phytoplankton · Succession · Response times · Nutrients · Runoff • Bottom-up · Top-down

Resale or republication not permitted without written consent of the publisher

\section{INTRODUCTION}

Much of our view of the world ocean derives from sampling that is not designed to characterize shortterm changes in the marine environment. Natural events can alter water-column conditions on short time scales, but the episodic nature of many perturbation events causes them to be chronically undersampled. Data on ecosystem responses are therefore often serendipitous (e.g. Roman et al. 1995). However, perturbations can play a significant role in structuring plankton communities and dynamics. In particular, episodic nutrient inputs can shift the balance between growth and grazing in plankton communities, prompting a successional response in primary and secondary production (e.g. Margalef 1967). These biological responses may have significant implications for processes of regional importance, such as fish production, as well as the magnitudes of global carbon cycling and export (Wassmann 1998).

Ecosystem response to transient nutrient inputs should vary with the magnitude of the input and the type and extent of nutrient limitation, but it may also depend on the type of system in which it occurs. In 
particular, temperate and tropical systems are likely to respond differently to episodic nutrient inputs due to fundamental differences in environmental conditions, such as temperature and light availability (Saenger \& Holmes 1992, Banse 1995, Verity \& Smetacek 1996, Kiørboe 1998, Wassmann 1998). Temperate phytoplankton respond to nutrient inputs seasonally, depending on light availability, and such systems often show significant decoupling between phytoplankton and zooplankton community dynamics during the spring, with low temperatures and adaptations to seasonal differences in production resulting in significant lags in zooplankton response (e.g. Colebrook 1979). While this lag in grazer response may decrease during summer and fall and at high latitudes, where copepod populations can overwinter at depth (Wassmann 1998), conditions often inhibit phytoplankton and zooplankton from responding swiftly to changes in resource availability.

In tropical systems, light is abundant and temperatures are high throughout the year, so the dynamics of planktonic primary producers, herbivores and predators are more tightly coupled. Food-web responses to change can therefore occur quite rapidly. High lightlevels should favor a strong and fast phytoplankton response to nutrient additions, and the zooplankton response should be facilitated by the presence of a persistent, metabolically active community. For instance, open-ocean tropical zooplankton communities have been shown to respond rapidly to upwelling events (Vinogradov \& Voronina 1963, Timonin 1969, Roman et al. 2002), and to the passage of instability waves (Roman et al. 1995). The relevant time scale is days to weeks, as opposed to the weeks-to-months scale of the classic temperate and boreal blooms.

Differences between temperate and tropical zooplankton responses to nutrient perturbations may be even greater in coastal waters, where storm runoff can deliver large pulses of nutrients to nearshore waters. Storm runoff commonly contains high concentrations of dissolved nutrients, especially nitrogen, which often limits phytoplankton growth. However, despite their potential importance, few studies have investigated the impact of episodic storm nutrient inputs on tropical coastal plankton communities, and most of these have focused on phytoplankton response (e.g. Jokiel et al. 1993, Ringuet \& Mackenzie 2005). Thus, the response of tropical zooplankton to these events, and perhaps more importantly, the subsequent top-down feedbacks to lower levels of the food web, remain largely unknown.

The goal of this study was to characterize the relative response times and successional patterns of tropical zooplankton to a natural nutrient perturbation event, and to address issues of bottom-up vs. top-down con- trols on plankton community structure. We expected that storm inputs of new nutrients would result in increased zooplankton abundance and biomass in this normally nutrient-limited system, and that this response would vary among groups of zooplankton due to differing reproductive and feeding strategies. Specifically, with instantaneous growth rates of $\sim 2 \mathrm{~d}^{-1}$ at these temperatures (Hopcroft et al. 1998a), and high prey clearance rates (Scheinberg et al. 2005), appendicularians were expected to respond rapidly and to exert significant grazing pressure on phytoplankton. Copepod populations would be likely to increase more gradually than appendicularians due to their multistep developmental process, with growth rates on the order of $\sim 1 \mathrm{~d}^{-1}$ (Huntley \& Lopez 1992). Planktonic carnivores, such as chaetognaths, were also anticipated to respond to an increase in prey concentrations, leading to increased predation pressure and significant top-down control on community structure and abundance (cf. Szyper 1976, Kimmerer 1984).

\section{MATERIALS AND METHODS}

Study site. Kaneohe Bay is a subtropical embayment on the island of Oahu, Hawaii (Fig. 1). The southern sector of the bay is the most enclosed, with restricted exchange with offshore waters. The south bay receives runoff primarily from 2 streams on the west shore (Kaneohe and Keaahala, Fig. 1). Stream discharges are characterized by prolonged periods of low flow interrupted by intense runoff associated with storms. Storm runoff is highly enriched in inorganic nutrients (Hoover 2002), and results in extensive plumes in the bay, with most occurring along the west shore and extending toward the NW (Ringuet \& Mackenzie 2005). Sampling for this study was conducted at Stn C Buoy, which is centrally located within the typical plume area (Fig. 1). Water depths at C Buoy average about $13 \mathrm{~m}$, typical of the central basin of the south bay.

Meteorology. Rainfall and runoff into Kaneohe Bay were determined using data from the United States Geological Survey (USGS) Luluku rain gage, USGS Kaneohe stream gage, and the Hawaii Institute of Marine Biology (HIMB) rain gage on Coconut Island (Fig. 1). Solar radiation, wind speed and wind direction also were obtained from the HIMB weather station. Tidal data were obtained from online records from the National Oceanographic and Atmospheric Administration (NOAA) tidal gage on Coconut Island (www.noaa.gov).

Field collection. Sampling was initiated following the first major storm event of the wet season in 2003. Monitoring of water-column physical and chemical parameters began on the first day of the storm, 29 Novem- 

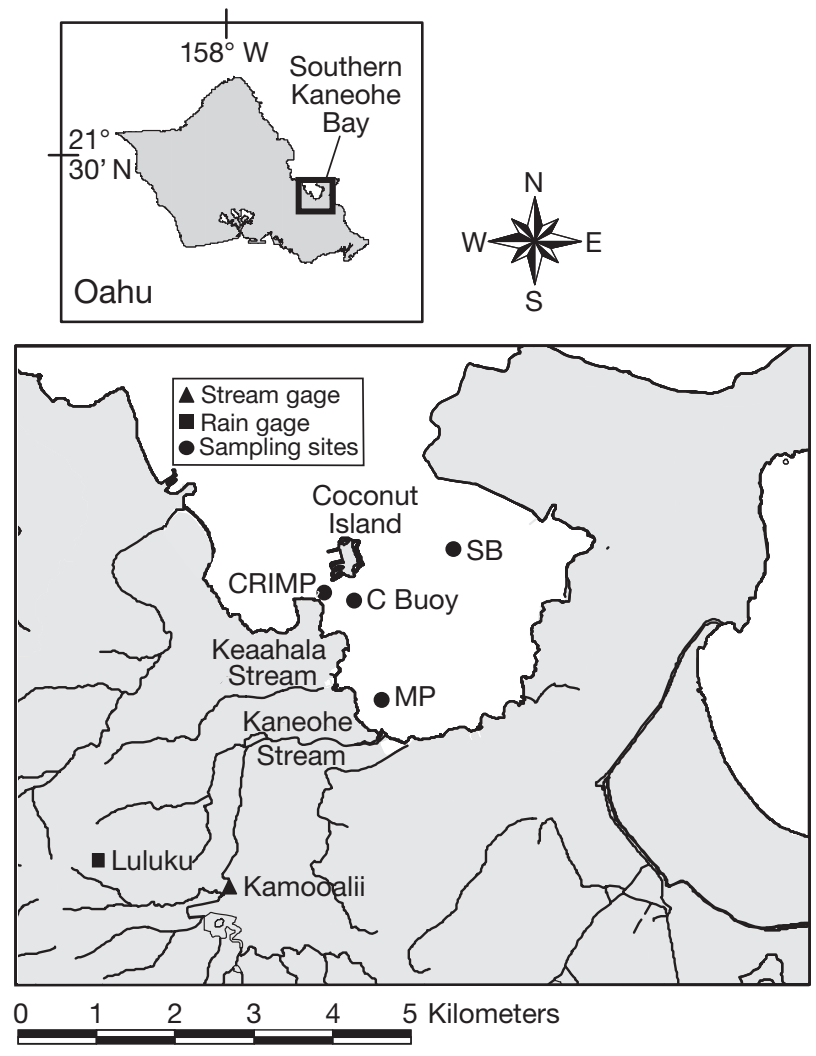

Fig. 1. Study site in southern Kaneohe Bay, Oahu, Hawaii. Samples for nutrient, pigment and zooplankton analyses were collected at Stn C Buoy and compared to the results of previous sampling conducted at Stns MP and SB (Kinzie et al. 2001). CRIMP indicates the site of the Coral Reef Instrumented Monitoring Program established in conjunction with the present study (DeCarlo et al. in press)

ber, and extended daily through 20 December 2003. Subsequent sampling was performed approximately every 2 weeks until 9 March 2004. Zooplankton sampling was initiated on 5 December. Point-sampling typically cannot distinguish between changes due to the temporal evolution of parameters and changes due to the advection of water past the sampling point. However, the residence time of water in southern Kaneohe Bay is long ( 13 d, Smith et al. 1981) compared to the rapid growth rates $\left(>1 \mathrm{~d}^{-1}\right)$ of both autotrophic and heterotrophic populations at these temperatures (Newbury \& Bartholomew 1976, Szyper 1976, Landry et al. 1984, Laws et al. 1984, Nielsen \& Kiørboe 1991, Hopcroft et al. 1998a,b), and the lateral extent of the plume was large $(\mathrm{km})$ compared to net advection velocities expected in the vicinity of Stn C Buoy (surface velocities on the order of $300 \mathrm{~m} \mathrm{~d}^{-1}$, less at depth; Bathen 1968, D. Hoover unpubl. data). The cited residence time is for 'normal' conditions, but should not be significantly affected by high runoff, as the volume of stream water delivered to southern Kaneohe Bay during storms is still a small fraction of the total volume (Hoover 2002). Therefore, temporal changes at this site are believed to be determined primarily by in situ processes rather than advection.

Water-column profiling (temperature, salinity, dissolved oxygen, $\mathrm{pH}$, turbidity) was conducted using a YSI 6600 multi-parameter sonde. Surface-water samples $(\sim 10 \mathrm{~cm}$ depth) were collected in acid-washed HDPE bottles and processed onshore for salinity, dissolved nutrients (nitrate + nitrite, ammonium, soluble reactive phosphorus and silicate) and phytoplankton pigments (details of methodology in following subsection). Net tows (0.5 m diameter net, $64 \mu \mathrm{m}$ Nitex mesh) were conducted to determine micro- and mesozooplankton abundance. Vertical tows (0 to $12 \mathrm{~m}$ ) were performed manually to minimize damage to fragile gelatinous animals. The small mesh size was selected to allow collection of nauplii, juvenile and adult copepods (Hopcroft et al. 1998b), all post-hatching lifehistory sizes of appendicularians (Fenaux 1998) and early-stage chaetognaths (Baier \& Purcell 1997). Net tow samples were preserved in the field in 5\% (final concentration) borax-buffered formalin.

Dissolved nutrients. Nutrient samples were filtered through acid- and deionized $\mathrm{H}_{2} \mathrm{O}$-rinsed Whatman GF/C filters (nominal pore size 1.2 $\mu \mathrm{m}$ ). The filtrate was frozen for later analysis of dissolved nutrients (nitrate + nitrite $\left[\mathrm{NO}_{3}{ }^{-}+\mathrm{NO}_{2}{ }^{-}\right]$, hereafter referred to as nitrate; ammonia $\left[\mathrm{NH}_{4}^{+}\right]_{;}$soluble reactive phosphorus [SRP, historically reported as $\left.\mathrm{PO}_{4}^{-3}\right]$; and silicate $\left[\mathrm{Si}(\mathrm{OH})_{4}\right]$ ) using a Technicon AAII nutrient autoanalyzer and standard colorimetric methods (UNESCO 1994).

Phytoplankton pigment concentrations and abundance. Samples were processed for pigment analyses by high-performance liquid chromatography (HPLC). Aliquots (300 to $1000 \mathrm{ml}$ ) were filtered onto Whatman GF/C glass-fiber filters and frozen at $-80^{\circ} \mathrm{C}$ for later analysis. Prior to analysis, filters were placed in $5 \mathrm{ml}$ of $100 \%$ acetone, ground in a glass tissue-homogenizer and extracted for $24 \mathrm{~h}$ at $0^{\circ} \mathrm{C}$ in the dark. Pigment extracts were vortexed and centrifuged prior to analysis to remove cellular and filter debris. Samples (200 $\mu \mathrm{l})$ of a mixture of $0.3 \mathrm{ml} \mathrm{H}_{2} \mathrm{O}$ plus $3.0 \mathrm{ml}$ extract were injected into a Varian 9012 HPLC system equipped with a Varian 9300 autosampler, a Timberline column heater $\left(26^{\circ} \mathrm{C}\right)$, and Spherisorb $5 \mu \mathrm{m}$ ODS2 analytical $(4.6 \times 250 \mathrm{~mm})$ column and corresponding guard cartridge. Pigments were detected with a ThermoSeparation UV2000 detector $(\lambda=436 \mathrm{~nm})$. Pigment analyses were performed using the procedures described in Bidigare et al. (2004).

The relative abundances of large net phytoplankton (>64 mm) were determined from preserved net tows. Taxonomic composition was assessed from microscopical cell counts according to Tomas (1997), using a Zeiss inverted microscope. 
Zooplankton abundance and biomass. Abundance: Preserved net-tow samples were rinsed on a $64 \mu \mathrm{m}$ mesh sieve to remove excess formalin, diluted to $100 \mathrm{ml}$ with $0.2 \mu \mathrm{m}$ filtered seawater, and stained with Rose Bengal (in isopropyl alcohol, $0.05 \%$ final concentration). A minimum of 100 individuals of each dominant $\left(\geq 0.1\right.$ ind. $\left.\mathrm{l}^{-1}\right)$ zooplankton group was counted using a Leica Z9.5 stereomicroscope with an ocular micrometer. All dominant adults, juveniles and nauplii were classified to species and measured to the nearest $20 \mu \mathrm{m}(\mathrm{n} \geq 50)$. Chaetognaths were separated into 3 life stages based on gonad development (Stages 1, 2 and 3) according to Casanova (1999). Shrinkage of preserved gelatinous specimens was assumed to be $12 \%$ (Scheinberg et al. 2005). Dominant copepods, chaetognaths, appendicularians and cladocerans were identified to species according to Bückmann \& Knapp (1975), Fenaux (1993), Bradford-Grieve et al. (1999), Casanova (1999) and Onbé (1999). Hydromedusae were identified with the help of Wrobel \& Mills (1998) and Bouillon (1999). All other dominant organisms were sorted to class or order. More motile planktonic predators, such as larval fishes, were not sampled quantitatively and were not counted.

Biomass: Appendicularian biomass was estimated from the ash-free dry weight (AFDW, $\mu \mathrm{g})$ to trunk length $(\mathrm{TL}, \mu \mathrm{m})$ relationships of Hopcroft et al. (1998a) for Oikopleura longicauda $(\log \mathrm{AFDW}=2.47 \log \mathrm{TL}$ - 6.10) and of Alldredge (1976) for O. fusiformis $(\log \mathrm{AFDW}=4.21 \log \mathrm{TL}-$ 11.35), as reported in Hopcroft et al. (1998a). Appendicularian trunk length was measured as the distance from the tip of the mouth to the posterior edge of the trunk. Adult copepod biomass was estimated from the prosome length $(\mathrm{L}, \mathrm{mm})$ and ash-free dry weight (AFDW, $\mu \mathrm{g}$ ) relationships of Hopcroft et al. (1998b) for Oithona simplex $(\log \mathrm{AFDW}=3.47, \log \mathrm{L}-8.76)$, Oithona nana ( $\log \mathrm{AFDW}=3.16, \log \mathrm{L}-8.18)$, Parvocalanus crassirostris (ln AFDW $=3.25$, $\ln \mathrm{L}-19.65$ ) and total nauplii (ln AFDW = $2.48, \ln \mathrm{L}-15.70)$. A length/weight relationship was not available for Bestiolina similis, so the relationship of $P$. crassirostris was used for this similarly-shaped copepod species. The biomass of each chaetognath life stage was estimated from the length $(\mathrm{L}, \mathrm{mm})$ and carbon $(C, \mu g)$ relationship of Szyper (1976) for Sagitta enflata in Kaneohe Bay $\left(\mathrm{W}=0.0567 \mathrm{~L}^{2.83}\right)$. Hydromedusae biomass was estimated using the relationship of Båmstedt \& Martinussen (1999) for bell diameter $(\mathrm{L}, \mathrm{mm})$ and dry weight $(\mathrm{DW}, \mu \mathrm{g})$ of $\mathrm{DW}=$ $22.3 \mathrm{~L}^{1.99}$. Biomass was converted to carbon $(\mathrm{C})$ using a C:W ratio of 0.52 and a C:DW ratio of 0.45 , as in Alldredge (1981).

Statistics. The significance of variability in the plankton community in Kaneohe Bay following the storm event was determined using paired and non-paired Student's $t$-tests. Correlation analysis was used to determine relationships between variables, and their significance was established by regression analysis (Moore \& McCabe 1993). Unless otherwise noted, errors are reported as $95 \%$ confidence limits of the mean.

\section{RESULTS}

\section{Meteorological and hydrological data}

During the study period, 2 significant rainfall/runoff events occurred (Fig. 2). The first and largest was on 29
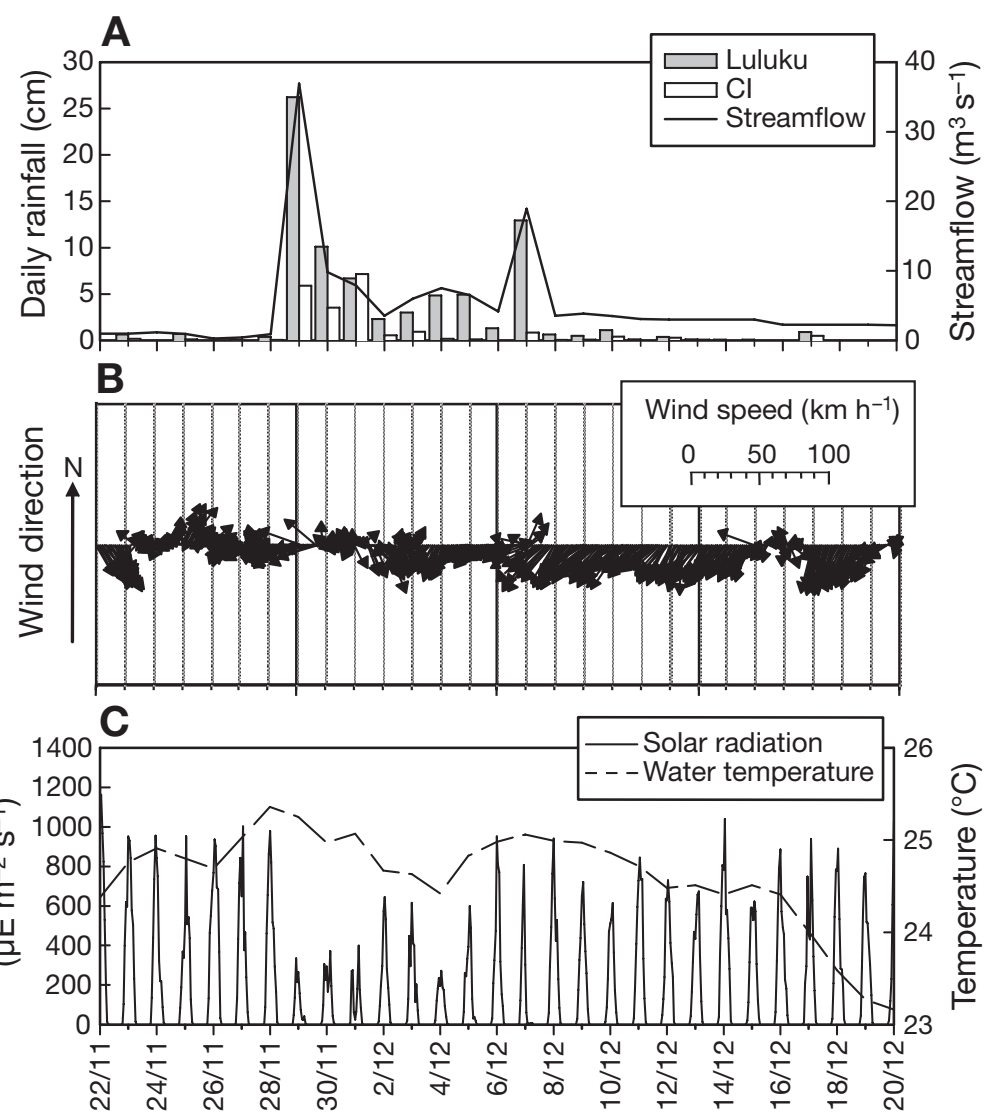

Fig. 2. Meteorological and hydrological conditions in southern Kaneohe Bay prior to and following the 29 November 2003 storm event. (A) Daily rainfall and streamflow from the United States Geological Survey (USGS) Luluku rain gage and Kamooalii stream gage, and from the Hawaii Institute of Marine Biology (HIMB) rain gage on Coconut Island (CI); (B) wind speed and direction, and (C) solar radiation and water temperature, also from HIMB 
November, with a daily rainfall total of $26 \mathrm{~cm}$ at the Luluku rain gage resulting in an average streamflow of $37 \mathrm{~m}^{3} \mathrm{~s}^{-1}$ at the Kaneohe stream gage. Rainfall and runoff declined gradually over the following $8 \mathrm{~d}$ until the second, less intense, storm occurred on 7 December. The flux of freshwater to the bay on 29 November 2003 was roughly 200 -fold greater than baseline conditions. Rainfall and average streamflow during this storm were $13 \mathrm{~cm}$ and $19 \mathrm{~m}^{3}$ $\mathrm{s}^{-1}$, respectively.

Winds were light and variable in late November and early December until strong trade (NE) wind conditions returned on 7 December (Fig. 2). Solar radiation decreased dramatically with the onset of the storm on 29 November, and remained low until 6 December due to persistent cloud cover (Fig. 2). Surface-water temperature varied only modestly until $7 \mathrm{De}-$ cember, when it dropped by $>1^{\circ} \mathrm{C}$ (Fig. 2).

After the initial runoff pulse from the first storm event, favorable meteorological and hydrodynamic conditions resulted in a persistent, stable, brackish lens of surface water (1 to

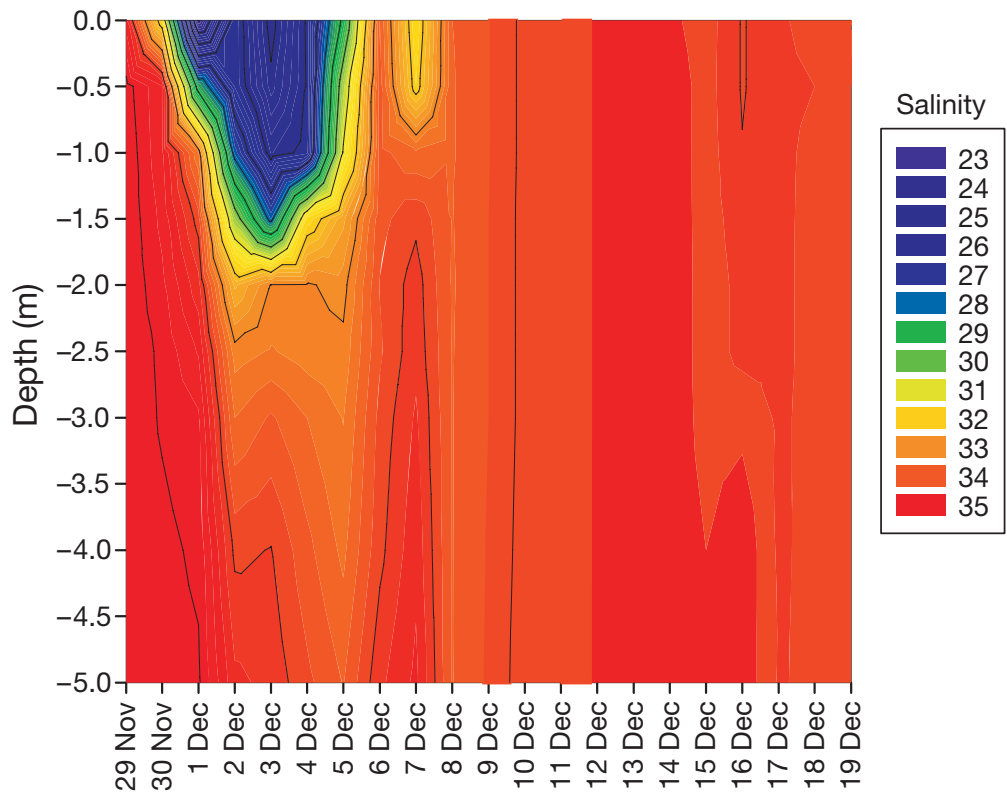

Fig. 3. Surface (0 to $5 \mathrm{~m}$ ) salinity at Stn C Buoy following the 29 November 2003 storm event. Minimum surface salinities of 23 to 25 were observed from 1 to 3 December. Salinities below $5 \mathrm{~m}$ were $\geq 33.6$ throughout the study period. Contour lines $=1.0$ $2 \mathrm{~m}$ thick) that lasted through 5 December (Fig. 3). The lens spread laterally across the bay to Stn SB (Fig. 1) by 5 December. The second storm event resulted in a slight freshening of surface waters on 7 December, but the water column was well mixed again within $24 \mathrm{~h}$ (Fig. 3).

\section{Nutrients and total chlorophyll a}

Dissolved nitrate, silicate and SRP increased significantly in surface waters immediately following the first storm event on 29 November. Concentrations were 1 order of magnitude higher than typical historical levels measured at a nearby station (Stn MP) and in the center of the southern basin at Stn SB during fortnightly monitoring from 1998 to 2001 (present Fig. 4 A,B, and Kinzie et al. 2001). $\mathrm{NH}_{4}{ }^{+}$initially was low, but increased dramatically on 6 December, $5 \mathrm{~d}$ after the initial nitrate and SRP peaks. Nitrate and silicate levels declined rapidly in the days immediately following the storm. Both $\mathrm{NH}_{4}{ }^{+}$and SRP remained well above baseline concentrations throughout the latter part of the study period, but nitrate and silicate continued to decline and dropped below typical levels in the last week of the study period. The second storm-runoff event on 7 December did not result in any appreciable changes in nutrient concentrations.

Total chlorophyll a ( $\mathrm{chl} \mathrm{a}$ ) increased dramatically on 3 December, peaked on 4 December, and then declined to baseline levels by 7 December (Fig. 4C), coincident

with the breakdown in water-column stratification on 6 December. Subsequently, chl a concentrations increased gradually but steadily for the remainder of the sampling period, with a secondary peak of $3 \mu \mathrm{g} \mathrm{l}^{-1}$ on 14 to 15 December. Chl a had returned to baseline concentrations by the next sampling on 13 January 2004.

\section{Phytoplankton community composition}

Changes in the phytoplankton population are indicated by changes in diagnostic accessory pigments (Fig. 5). Peridinin, the indicator for autotrophic dinoflagellates, exhibited an initial $1 \mathrm{~d}$ peak on 2 December, but was near or below detection for most of the study period. Prasinoxanthin increased rapidly on 3 December and peaked on 4 December. Corresponding increases in other prasinophyte-identifying pigments (zeaxanthin, violaxanthin and chl $b$ [data not shown]) indicate that these small, autotrophic flagellates bloomed directly following the dinoflagellates. Zeaxanthin is also associated with cyanobacteria; its increase between 3 and 6 December may indicate a parallel increase in photosynthetic bacteria, but while sub-micron-sized Synechococcus spp. are abundant in Kaneohe Bay (Scheinberg et al. 2005), they are likely to be underrepresented in our pigment sampling due to the relatively large pore size of the GF/C filters used. Fucoxanthin concentrations indicate that diatoms also increased following the first storm. While 

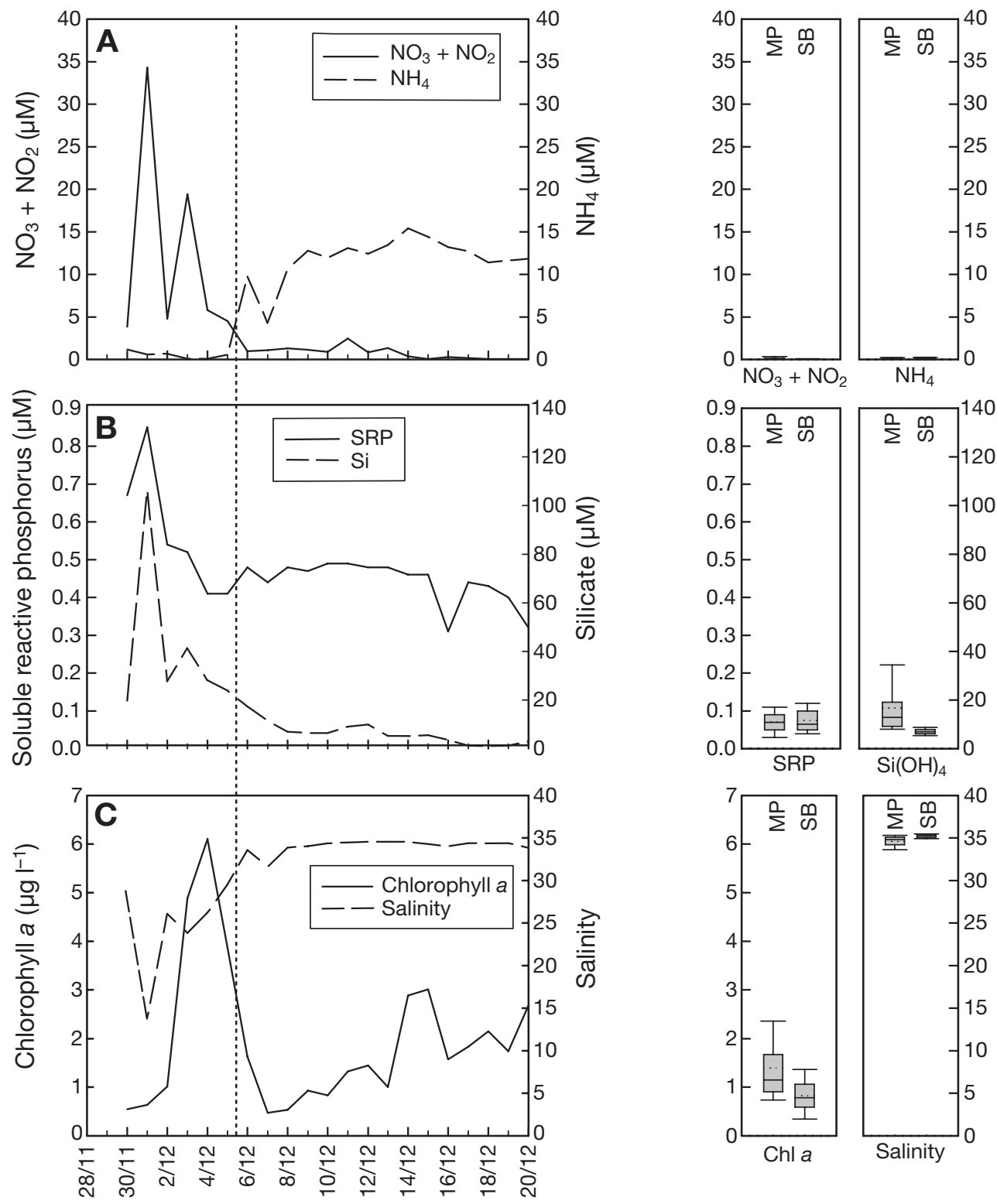

Fig. 4. (A) Dissolved inorganic nitrogen, (B) soluble reactive phosphorus (SRP) and silicate, and (C) total chl a and salinity at Stn C Buoy; dotted vertical line separates stratified water-column conditions (through 5 December 2003) from well-mixed conditions (6 December and later). Boxplots (right): distribution of data from fortnightly samples collected from October 1998 to July 2001 (Kinzie et al. 2001) at Stns MP and SB (see Fig. 1). Data plotted on identical scales to highlight changes due to storm event (data from C Buoy would normally be intermediate between those of MP and SB). In boxplots, box = 25th through 75th percentiles, solid and dashed lines within box are mean and median, respectively, and 'whiskers' extending from bottom and top of box are 5th and 95th percentiles, respectively

prasinoxanthin and fucoxanthin both peaked on 4 December, prasinoxanthin values were already high on 3 December, indicating that the initial diatom response lagged that of prasinophytes by $\sim 1 \mathrm{~d}$. Fucoxanthin concentrations declined with those of other pigments following the breakdown of water-column stratification on 6 December, but then recovered to even higher levels late in the study period. Similar trends between total chl $a$ and fucoxanthin, and low concentrations of other phytoplankton accessory pigments, suggest that diatoms dominated the phytoplankton community during this period. Minor increases in peridinin and zeaxanthin indicate smaller contributions by dinoflagellates and cyanobacteria. Accessory pigments and total $\mathrm{chl} a$ had returned to relatively typical concentrations by 13 January.

Net $(>64 \mu \mathrm{m})$ phytoplankton samples verify the progression from small phytoplankton to diatoms (Fig. 6). 


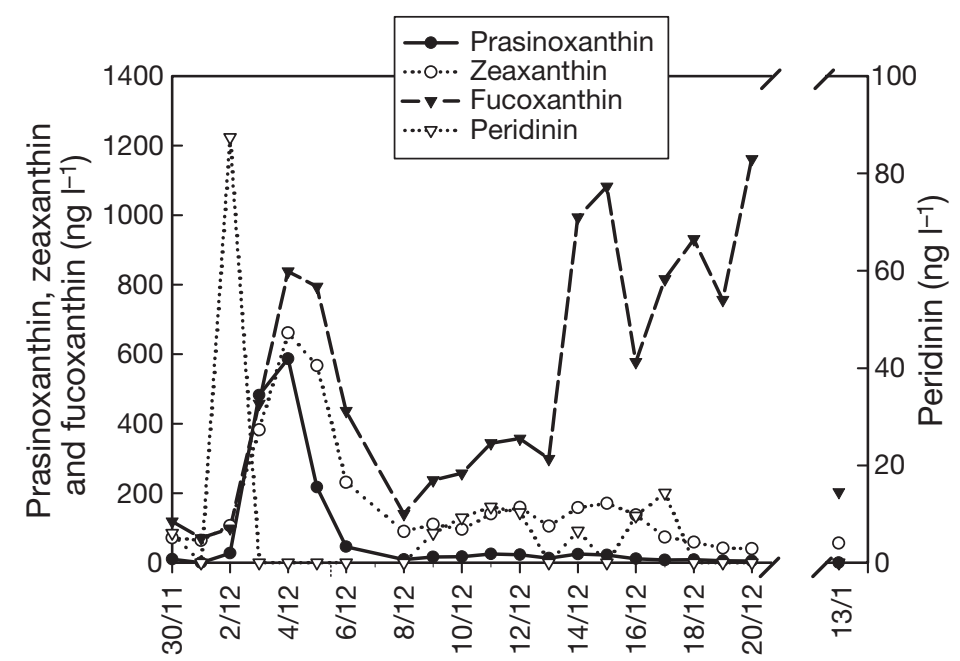

Fig. 5. Phytoplankton pigments in surface-water samples from Stn C Buoy from 30 November to 20 December 2003. Data from 13 January 2004 is also shown to illustrate return of phytoplankton population to more typical conditions

Large cells were absent from our samples from 5 to 8 December, except for Protoperidinium sp., a typically heterotrophic dinoflagellate genus of not sufficiently clear trophic status to include here. A sparse population of the autotrophic dinoflagellate Ceratium spp. appeared on 9 December, followed by diatoms on $10 \mathrm{De}-$ cember, with a peak on 14 December, as also seen in the fucoxanthin data. From 10 to 14 December, the composition of the diatom community shifted from a mixed assemblage of the pennate diatoms Haslea spp., Pleurosigma spp. and Thalassionema nitzchoides and the dinoflagellates Ceratium spp., to the centric chain diatoms Guardia spp. and then Chaetoceros spp. Chaetoceros spp. dominated net phytoplankton on 13 to 14 December, leading into the fucoxanthin peak on 14 to 15 December. The relative importance of Chaetoceros spp. decreased after 14 December, but large diatoms were still abundant until the end of the study period. Protoperidinium sp. (similar to $P$. divergens, Jeong et al. 1997) also exhibited a gradual increase in relative abundance after 14 December.

\section{Zooplankton abundance and community composition}

Grazers. Zooplankton abundances prior to, during and following the storm event on 29 November are presented in Table 1. Grazers (consumers of both autotrophic and heterotrophic prey) consisted primarily of the copepods Oithona simplex, Oithona nana, Bestiolina similis and Parvocalanus crassirostris, the appendicularians Oikopleura longicauda and Oikopleura fusiformis, the cladoceran Penilia avirostris, and larval bivalves and polychaetes. Copepods were the most abundant zooplankton group during the study, particularly the smallest species, Oithona simplex and P. crassirostris. Copepod succession varied among species and developmental stages. Adult copepods were most abundant immediately following the breakdown in water-column stratification (Fig. 7A), with the exception of Oithona nana, whose abundance varied little throughout the study. Calanoid adults and juveniles exhibited a positive response to the storm event, and abundances exceeded historical values for the majority of the study period. In contrast, cyclopoid abundances were less than or equal to abundances previously measured in Kaneohe Bay (present Table 1 and Scheinberg 2004).

Abundances of the appendicularians Oikopleura longicauda and $O$. fusiformis varied significantly throughout the study period (Fig. 7B). Abundance of both species peaked on 9 December, with O. longicauda increasing from 0.4 to 2.5 ind. $\mathrm{l}^{-1}$ and $O$. fusiformis from 0.1 to 0.6 ind. $\mathrm{l}^{-1}$ in a single day. $O$. longicauda always was more abundant than $O$. fusi-

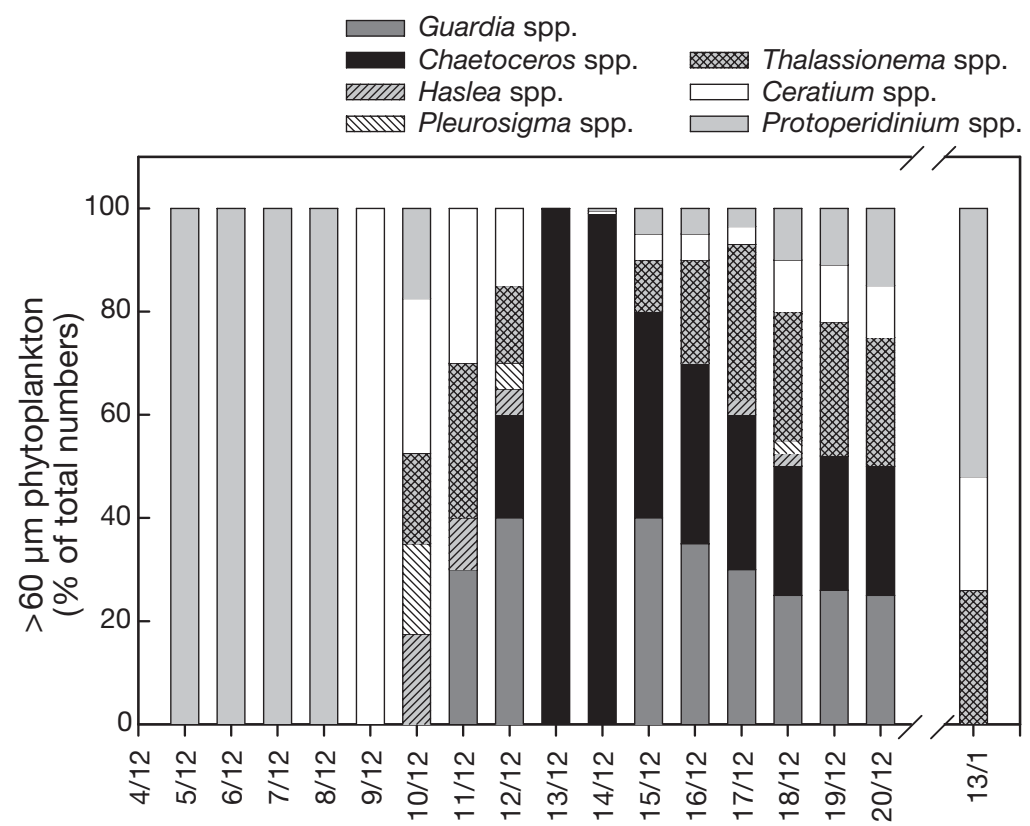

Fig. 6. Relative abundance of $>60 \mu \mathrm{m}$ phytoplankton collected in vertical, 0 to $13 \mathrm{~m}$ net tows at Stn C Buoy in December 2003. Protoperidinium sp. is included, although taxonomically it is most similar to the heterotrophic species $P$. divergens 
Table 1. Zooplankton abundance (ind. $\mathrm{l}^{-1}$ ) at Stn C Buoy. Pre-storm data was collected from 2001 to 2002 (n = 30, Scheinberg 2004). Storm data was collected in December $2003(\mathrm{n}=16)$, and post-storm data was collected from January to March, $2004(\mathrm{n}=4)$

\begin{tabular}{|c|c|c|c|c|c|c|}
\hline \multirow{2}{*}{ Species } & \multicolumn{2}{|c|}{ Pre-storm } & \multicolumn{2}{|c|}{- Storm } & \multicolumn{2}{|c|}{ - Post-storm } \\
\hline & Range & Mean \pm CI & Range & Mean \pm CI & Range & Mean \pm CI \\
\hline \multicolumn{7}{|l|}{ Copepods } \\
\hline Nauplii & $12-68$ & $34 \pm 6$ & $6.7-63$ & $36 \pm 9$ & $33-55$ & $40 \pm 10$ \\
\hline Calanoid juveniles & $1.2-12$ & $5.1 \pm 1.0$ & $3.8-15$ & $8.8 \pm 1.8$ & $4.4-16$ & $7.9 \pm 5.5$ \\
\hline Cyclopoid juveniles & $3.5-26$ & $13 \pm 2$ & $1.1-5.9$ & $3.8 \pm 0.7$ & $6.8-13$ & $9.1 \pm 2.6$ \\
\hline \multicolumn{7}{|l|}{ Calanoid adults } \\
\hline Bestiolina similis & $0.02-2.7$ & $0.61 \pm 0.21$ & $0.52-3.4$ & $1.4 \pm 0.4$ & $0.21-1.1$ & $0.55 \pm 0.40$ \\
\hline Parvocalanus crassirostris & $0.46-3.2$ & $1.6 \pm 0.27$ & $2.1-8.7$ & $4.3 \pm 0.8$ & $0.96-4.7$ & $2.5 \pm 1.6$ \\
\hline \multicolumn{7}{|c|}{ Cyclopoid adults } \\
\hline Oithona simplex & $1.0-19$ & $6.3 \pm 1.2$ & $1.6-8.8$ & $4.9 \pm 1.0$ & $4.3-8.7$ & $6.9 \pm 1.8$ \\
\hline Oithona nana & $0.08-2.04$ & $0.51 \pm 0.14$ & $0.11-0.85$ & $0.53 \pm 0.11$ & $0.28-2.04$ & $0.93 \pm 0.76$ \\
\hline \multicolumn{7}{|l|}{ Appendicularians } \\
\hline \multicolumn{7}{|l|}{ Juveniles } \\
\hline Oikopleura longicauda & $0.00-0.98$ & $0.19 \pm 0.11$ & $0.05-1.3$ & $0.35 \pm 0.16$ & $0.02-0.28$ & $0.12 \pm 0.12$ \\
\hline Oikopleura fusiformis & $0.00-0.44$ & $42 \pm 39 \times 10^{-3}$ & $0.01-0.28$ & $69 \pm 36 \times 10^{-3}$ & $0.01-0.16$ & $0.10 \pm 0.07$ \\
\hline \multicolumn{7}{|l|}{ Adults } \\
\hline Oikopleura longicauda & $0.00-0.72$ & $0.12 \pm 0.07$ & $0.09-1.4$ & $0.43 \pm 0.17$ & $0.09-0.83$ & $0.34 \pm 0.32$ \\
\hline Oikopleura fusiformis & $0.00-0.27$ & $24 \pm 25 \times 10^{-3}$ & $0.02-0.51$ & $0.14 \pm 0.06$ & $0.11-0.56$ & $0.33 \pm 0.18$ \\
\hline \multicolumn{7}{|l|}{ Chaetognaths (Sagitta enflata) } \\
\hline Stage 1 & $0.04-0.75$ & $0.33 \pm 0.07$ & $0.05-0.74$ & $0.39 \pm 0.11$ & $0.16-0.37$ & $0.27 \pm 0.09$ \\
\hline Stage 2 & $0.00-0.11$ & $17 \pm 7 \times 10^{-3}$ & $2-11 \times 10^{-3}$ & $3 \quad 60 \pm 10 \times 10^{-4}$ & $3-28 \times 10^{-3}$ & $313 \pm 11 \times 10^{-3}$ \\
\hline Stage 3 & $0-60 \times 10^{-3}$ & $17 \pm 7 \times 10^{-3}$ & $1-18 \times 10^{-3}$ & $3 \quad 90 \pm 20 \times 10^{-4}$ & $3-11 \times 10^{-3}$ & $370 \pm 30 \times 10^{-4}$ \\
\hline \multicolumn{7}{|l|}{ Hydromedusae } \\
\hline Small hydromedusa & $0.0-1.6$ & $0.23 \pm 0.13$ & $0.01-0.22$ & $82 \pm 34 \times 10^{-3}$ & $0-46 \times 10^{-3}$ & $319 \pm 19 \times 10^{-3}$ \\
\hline Obelia sp. & $0.00-0.15$ & $20 \pm 14 \times 10^{-3}$ & $3-20 \times 10^{-3}$ & $9 \pm 3 \times 10^{-3}$ & $0-57 \times 10^{-3}$ & $326 \pm 25 \times 10^{-3}$ \\
\hline \multicolumn{7}{|l|}{ Meroplankton } \\
\hline Bivalve larvae & $0.00-0.23$ & $15 \pm 5 \times 10^{-3}$ & $0.00-0.57$ & $0.16 \pm 0.08$ & $0.20-0.44$ & $0.33 \pm 0.41$ \\
\hline Polychaete larvae & $0.00-0.65$ & $11 \pm 5 \times 10^{-3}$ & $0.11-0.91$ & $0.45 \pm 0.13$ & $0.31-0.66$ & $0.41 \pm 0.16$ \\
\hline Penelia avirostris & $0-20 \times 10^{-3}$ & $10 \pm 10 \times 10^{-3}$ & $2-33 \times 10^{-3}$ & $3 \quad 16 \pm 5 \times 10^{-3}$ & $0.00-0.12$ & $56 \pm 49 \times 10^{-3}$ \\
\hline
\end{tabular}

formis. Juvenile appendicularians exhibited trends similar to the adults (Fig. 7B).

Meroplankton also exhibited a response following the storm event and breakdown of water-column stratification. Bivalve abundance increased by $>1$ order of magnitude, from 0.02 to 0.6 ind. $\mathrm{l}^{-1}$, between 8 and 10 December, and then decreased to more typical concentrations. Polychaetes increased on December 8, reaching maximum abundances on 12 and 13 December that were over 2-fold higher than those recorded during the 2001 sampling. Penilia avirostris also peaked on 13 December, and was consistently more abundant than historical values (present Table 1, and Scheinberg 2004). Other omnivores, such as larval gastropods and decapods, comprised a minor portion of the zooplankton community (mean abundances $<0.01$ ind. $\mathrm{l}^{-1}$ ).

Predators. The dominant planktonic predators in the bay during the study period were the chaetognath Sagitta enflata, the hydromedusa, Obelia sp., and an unidentified, smaller hydromedusa. A significant, gradual increase in chaetognaths was evident over the $15 \mathrm{~d}$ sampling period $(\mathrm{p}<0.05)$, but the trend was primarily due to small, Stage 1 individuals (Fig. 7C). Stage
3 adult chaetognaths also increased, but fluctuated strongly, while no trend in abundance was observed for Stage 2 chaetognaths. Hydromedusae varied significantly in abundance during the sampling period (Fig. 7D). The small, unidentified hydromedusa increased roughly exponentially from 0.01 ind. $1^{-1}$ on 5 December to 0.57 ind. $\mathrm{l}^{-1}$ on 20 December. In contrast, Obelia sp. peaked earlier at 0.02 ind. $1^{-1}$ on 10 December, and then remained at intermediate levels through most of the sampling period. The apparent increase on 20 December may be real, as post-storm sampling on 13 January gave the highest Obelia sp. densities.

\section{Zooplankton biomass}

Temporal changes in zooplankton biomass are illustrated in Fig. 8. Copepods dominated the biomass on almost all days sampled, and variations in adult copepod biomass were responsible for most of the variability in zooplankton biomass, except during the appendicularian bloom from 9 to 10 December. Predator biomass (chaetognaths and hydromedusae) typi- 
cally was a small to modest fraction of the total (12 to $30 \%$ ), with higher proportions toward the end of the study period.

\section{DISCUSSION}

This study was conducted to characterize the relative response times and successional pattern of zooplankton following a natural nutrient-perturbation event, and to address issues of bottom-up vs. top-down control. The large magnitude of the 29 November storm, coupled with low wind speed and tidal exchange, resulted in optimal conditions for development of a persistent runoff plume, a large-scale phytoplankton bloom, and the opportunity to quantify the subsequent response of primary and secondary planktonic consumers. Responses were observed in both phytoplankton and zooplankton populations, but the degree of response varied within groups, reflecting significant interactions between phytoplankton, grazers and predators.

In general, successional patterns were similar to those observed at upwelling regions in the equatorial Pacific and Indian Oceans, where studies utilized distance from the upwelling as a proxy for time. For instance, Vinogradov \& Voronina (1963) and Timonin (1969) observed an increase in zooplankton abundance and a shift in community structure, from herbivores and omnivores to predators, north and south of upwelling regions. Increases in zooplankton rate-processes and biomass also have been observed with increasing distance (a proxy of time) from an upwelling zone (Roman et al. 2002).

\section{Phytoplankton succession}

Phytoplankton species variation during bloom development played an important role in the response of the zooplankton grazer community with respect to the size and availability of ingestible food. Watercolumn stratification during the $5 \mathrm{~d}$ immediately following the storm maintained high nutrient concentrations in a reduced-salinity surface layer, leading to a rapid increase in phytoplankton and a succession of phytoplankton groups, from dinoflagellates to prasinophytes to diatoms. Zeaxanthin data suggest that cyanobacteria also may have contributed to the initial bloom, but their contribution cannot be quantified directly from the pigment data alone due to the abundance of zeaxanthin-containing prasinophytes. The early appearance of dinoflagellates is consistent with observations that these organisms are better adapted to utilize high-nutrient concentrations under low-turbulence conditions than other phytoplankton groups (Sellner et al. 2001). Given the high sensitivity of dinoflagellates to small-scale turbulence
Fig. 7. Abundances of (A) adult, juvenile and naupliar copepods, (B) appendicularians, (C) chaetognaths, and (D) hydromedusae at Stn C Buoy. Pre-storm values are means of data from 30 samples collected in 2001 and 2002 (Scheinberg 2004). Storm values are means of 16 samples collected from 5 to 20 December 2003 (present study). Post-storm values are means of 4 samples collected from 13 January to 9 March 2004 (present study). Error bars are $\pm 2 \mathrm{SE}$ 


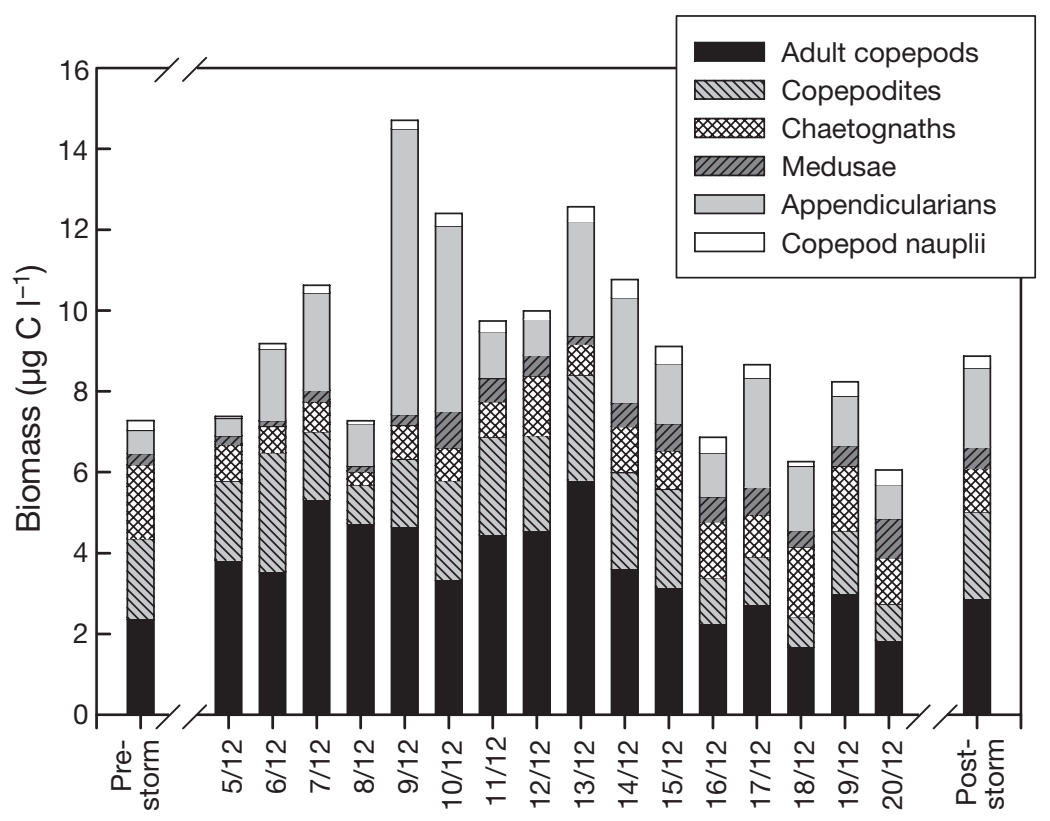

Fig. 8. Estimated zooplankton biomass at Stn C Buoy. Pre- and post-storm values as in Fig. 7. See 'Materials and methods' for details of biomass calculations

(Thomas \& Gibson 1990, Berdalet 1992), the short duration of their response could have been the result of a moderate increase in wind speed on 2 December. Dinoflagellates did not contribute significantly to chl a values after the initial bloom, although peridinin concentrations were measurable for much of the study period and large dinoflagellates were observed in net phytoplankton samples. Prasinophytes and diatoms contributed roughly equally to total chl a during the initial bloom based on chl a:accessory pigment ratios (Letelier et al. 1993).

The transient increase in prasinophytes during the initial few days of the Kaneohe Bay bloom bears some similarity to the early increase of prymnesiophytes in the iron-fertilized patch during the IronEx II experiment in the equatorial Pacific (Landry et al. 2000a). In both of these tropical ocean studies, and as generally observed in temperate systems as well (e.g. Malej et al. 1997), diatoms ultimately dominated the phytoplankton biomass response when nutrient constraints were lifted. However, this observed dominance is not entirely a consequence of the intrinsic ability of diatoms to grow faster than small flagellates; in fact, many small flagellates may have maximum growth rates at least comparable to if not exceeding those of large net phytoplankton (e.g. Munk \& Riley 1952, Kiørboe 1993, Sellner et al. 2001). Because, as observed here, the initial bursts of flagellates may actually decline when excess nutrients are still sufficient for rapid growth of large diatoms, differential size-dependent vulnerability to grazers, and particularly to small fast-growing grazers, clearly exerts a major influence on dominance and successional patterns in the bloom response. Since transient flagellate blooms occur in a short time-window between initial nutrient availability and rapid grazer response to increased food, they are easily overlooked in studies with coarse sampling frequency or collection techniques that anticipate and select for larger phytoplankton.

The termination of the initial phytoplankton bloom was characterized by a precipitous $2 \mathrm{~d}$ decline in chl a concentrations as water-column stratification broke down. Dilution was the primary cause of the chlorophyll decline, but persistently high nutrient concentrations suggest that phytoplankton should have been growing at high rates despite low standing stocks. In particular, although nitrate dropped below detection limits later in the study, high concentrations of $\mathrm{NH}_{4}^{+}$and SRP were available for phytoplankton growth. Given the shallow depth of the bay and its proximity to land, it also seems likely that trace nutrients, such as iron, would not have been limiting during the sampling period. In fact, the modest but steady increase in fucoxanthin concentrations throughout the study period demonstrates that diatom growth was not limited by macronutrient availability. Instead, the inability of phytoplankton to utilize the excess $\mathrm{NH}_{4}{ }^{+}$and SRP in the latter part of the study period is clearly consistent with top-down grazing control.

\section{Grazer response and impacts on phytoplankton}

Appendicularians exhibited the most dramatic numerical response to the storm-induced phytoplankton bloom. Biomass increased 6-fold after the breakdown in stratification, and abundances attained values only rarely observed in Kaneohe Bay (Scheinberg 2004). While Oikopleura longicauda always was more abundant than $O$. fusiformis, both species increased at similar rates and remained at or above their long-term means in Kaneohe Bay (present Fig. 7B, and Scheinberg 2004) throughout the sampling period.

Within the copepod assemblage, calanoids responded most quickly to increased food availability, as observed in the equatorial Pacific (Roman et al. 1995). Parvocalanus crassirostris reached abundances almost 6 -fold greater than those previously observed in Kaneohe Bay (Scheinberg 2004). In contrast, cyclopoids (Oithona simplex and O. nana) were depressed 
relative to historical densities, with maximum abundances less than half those observed in 2001 and 2002 ( $p<0.05)$. Biomass-specific ingestion rates of calanoid and cyclopoid copepods in Kaneohe Bay are comparable (Calbet et al. 2000); however, the larger size of calanoid copepods (wider and in most cases longer) may have given them an advantage with respect to handling larger cells during bloom conditions. Even small calanoids can generally consume diatoms (e.g. Frost 1972, Checkley 1980), while cyclopoids typically prefer smaller, more motile prey (Paffenhöfer 1993). The rather gradual increase in naupliar abundance suggests that copepods were able to take advantage of the food increase, but their reproductive responses were much slower than those of appendicularians (Fig. 7A,B). These results are consistent with reproductive responses observed in other temperate and tropical systems (Kiørboe \& Nielsen 1990, Rollwagen Bollens \& Landry 2000, Roman et al. 2002).

Previous work on storm-induced phytoplankton blooms in Kaneohe Bay showed that blooms are commonly terminated by phosphate-limitation (Ringuet \& Mackenzie 2005). However, as previously discussed, dissolved inorganic nitrogen and phosphorus never were low enough to limit production in the present study, suggesting that other factors terminated the initial bloom and maintained subsequent phytoplankton standing stocks at levels only slightly above normal for the bay. Among the omnivorous mesozooplankton, only the filter-feeding appendicularians had the capacity to graze rapidly enough to control primary production at phytoplankton growth rates observed in these waters under non-limiting conditions (typically $\sim 1 \mathrm{~d}^{-1}$; Laws \& Allen 1996, Ringuet \& Mackenzie 2005). Clearance rates of Oikopleura longicauda and O. fusiformis in Kaneohe Bay are 0.8 and 0.91 ind..$^{-1} \mathrm{~d}^{-1}$, respectively (Scheinberg et al. 2005). Thus, at the population densities encountered in this study, appendicularians had the potential to clear an average of $83 \pm 32 \%$ (range 30 to $260 \%$ ) of the water column daily. Copepods, bivalve larvae, polychaete larvae and Penilia avirostris also are all capable of consuming micro- and nanoplankton prey, albeit at much lower rates (Bayne 1983, Turner et al. 1988, 1998, Martin et al. 1996, Calbet et al. 2000). However, the grazing impacts of different zooplankton groups may have been modulated, in part, by changes in phytoplankton community composition.

Pigment data indicate that prasinophytes (2 to $30 \mu \mathrm{m}$ in size; Jeffrey \& Vesk 1997), cyanobacteria (1 to $20 \mu m_{i}$ Scheinberg 2004) and other non-diatom prey were held close to baseline concentrations by grazing throughout the latter portion of the study. However, a steady increase in total chl a and fucoxanthin concentrations and a small secondary diatom bloom on 14 to 15 December (Fig. 5) provide evidence for incomplete grazer control. One contributing factor may have been an increase in the mortality rates of omnivorous grazers. For example, diatoms increased only slowly when omnivorous zooplankton were most abundant, but they rose rapidly to a secondary bloom peak on 14 December, coincident with an increase in carnivores and the start of a steady decline in omnivorous zooplankton (Fig. 9). Even if a predation cascade provided a grazing release for diatoms, however, it is apparent that nondiatom phytoplankters enjoyed no such benefit. The answer may lie in smaller grazers, particularly herbivorous protists, which are notable for their ability to control smaller components of the phytoplankton community (e.g. Landry et al. 2000b). These micro-grazers also may have responded to a partial mortality release when the omnivorous mesozooplankton declined. Unfortunately, their dynamics and grazing roles cannot be assessed from the data available in the present study.

One other explanation for the differential grazing pressure on small and large cells is the size-selective grazing of appendicularians. Some appendicularians process only relatively small prey due to
Fig. 9. Trends in omnivorous and carnivorous zooplankton biomass at Stn C Buoy in December 2003. Chl a concentration shown for comparison, but 5 December data point excluded because $\mathrm{chl}$ a concentration is estimated from surface water, and the water column was not well-mixed until 6 December. Omnivore biomass decreased significantly following breakdown of water-column stratification (dashed line; $\mathrm{R}^{2}=0.25, \mathrm{p}<0.001$ ), while carnivore biomass increased (solid line; $\mathrm{R}^{2}=0.65, \mathrm{p}<0.001$ ). Poststorm value as in Fig. 7 
pore-size restrictions of their inlet filters (Fernández et al. 2004). For example, the $13 \mu \mathrm{m}$ inlet filter of Oikopleura fusiformis (Alldredge 1977) would exclude large diatoms. While $O$. longicauda does not have inlet filters, these small appendicularians (trunk length $370 \pm 30 \mu \mathrm{m}$ ) are still unlikely to be efficient grazers on the large, chain-forming diatoms that bloomed during the present study (individual cells typically $\geq 100 \mu \mathrm{m}$, with proportionately longer chains). Thus, changes in appendicularian abundance presumably translate most directly as grazing impacts on small cells. The relatively high abundances of appendicularians observed throughout this study would have been sufficient to exert a substantial mortality impact on phytoplankton prey within their optimal size range. Thus, while we generally assume that heterotrophic protists carry the load as grazers and regulators of small phytoplankton, in this case they would have had considerable help from metazooplankton consumers.

An additional consequence of an appendiculariandominated grazing response is the potential for enhanced export of phytoplankton production to the benthos through their mucus houses and fast-sinking fecal pellets. Appendicularians build and discard mucus houses on the order of 6 to 24 times a day at the temperatures observed during this study (Taguchi 1982, Sato et al. 2001), and discarded houses typically are enriched 10-fold in particulate organic matter (Taguchi 1982). In a previous study in Kaneohe Bay, discarded appendicularian houses and fecal pellets accounted for 60 and $13 \%$ of the annual particulate organic carbon (POC) flux, respectively (Taguchi 1982). House turnover rates presumably would be even higher due to increased clogging during a diatom bloom, so POC fluxes associated with discarded houses probably would have been enhanced during the study period. In addition, large diatoms could conceivably have negatively impacted appendicularian abundances by interfering with normal feeding processes and by increasing energy expenditure on house production at the expense of growth and reproduction.

\section{Predator response and impacts on grazers}

Variable predation by carnivorous zooplankton appears to have been a factor regulating omnivorous zooplankton abundance during the study period. Grazer biomass increased early, then declined after 13 December $\left(R^{2}=0.25, p<0.001\right)$, while predator biomass was depressed early and increased after 13 December $\left(\mathrm{R}^{2}=0.65, \mathrm{p}<0.001\right)$ (Fig. 9). In addition, populations of all of the major gelatinous predators exhibited short-term variability suggestive of classical predator/prey relationships with appendicularians and copepods, the most abundant grazers. The potential grazing impact of appendicularians was thus probably limited during this study due to predation by gelatinous zooplankton. Following their initial 2 d bloom, appendicularian abundances were held below $1 \mathrm{l}^{-1}$, despite a food supply sufficient to support maximum growth rates at these temperatures $\left(2.0 \pm 0.6 \mathrm{~d}^{-1}\right.$; Hopcroft et al. 1998a, as estimated in Scheinberg et al. 2005). Appendicularians are the preferred prey of $S a-$ gitta enflata in Kaneohe Bay (Kimmerer 1984). Based on a mean ingestion rate of 3 appendicularians chaetognath ${ }^{-1} \mathrm{~d}^{-1}$ (Kimmerer 1984), these predators could have consumed $>100 \%$ of the appendicularian standing stock on 9 of the $11 \mathrm{~d}$ following the appendicularian bloom. Gut contents of both Obelia sp. and the unidentified small hydromedusa indicate that these predators were also feeding on appendicularians. While the hydromedusae feeding rates are not known, Obelia sp. abundances closely followed appendicularian fluctuations, suggesting a possible predator-prey relationship. Predator control of appendicularians by hydromedusae and chaetognaths has also been suggested by long-term abundance patterns in Kaneohe Bay (Scheinberg 2004).

Declines in juvenile and adult copepod abundances were also correlated significantly with increases in Sagitta enflata $\left(\mathrm{R}^{2}=0.66\right.$ and 0.18 , respectively; $\left.\mathrm{p}<0.001\right)$ and with total hydromedusae $\left(\mathrm{R}^{2}=0.46\right.$ and 0.31 , respectively; $\mathrm{p}<0.01)$. S. enflata in Kaneohe Bay are known to feed on small copepods and could have consumed up to $160 \%$ of the copepod population per day as their abundances increased over the sampling period (Kimmerer 1984). However, the potential predatory impacts of chaetognaths probably vary with chaetognath life stage. Total chaetognaths, numerically dominated by juveniles, exhibited a significant, negative relationship with adult copepod abundances (particularly calanoids) over the sampling period, while Stage 3 (adult) chaetognaths followed the appendicularian peak by 1 to $2 \mathrm{~d}$. Although fluctuations in Stage 3 chaetognaths suggest that they may have been tightly coupled to their prey, prey dynamics also may have been influenced by unsampled predators, such as larval or adult fishes. Predation rates of hydromedusae on juvenile and adult copepods are unknown for this system, but the temporal patterns in their abundances also suggest that copepods were a food source.

Copepod nauplii, on the other hand, appear to have escaped predation by chaetognaths and/or hydromedusae following the storm event. There is evidence to suggest that nauplii experience a size-based refuge from predation by chaetognaths in Kaneohe Bay. In a study on selective predation, Kimmerer (1984) found that nauplii comprised only $8 \%$ of the diet of Sagitta 
enflata in Kaneohe Bay despite high abundances, and were selected against (electivity index $=-0.71$ ) as a prey item. Information on the predation rates of hydromedusae on copepod nauplii in Kaneohe Bay is not available. Nonetheless, while some species of hydromedusae prey on copepod nauplii (Mills 1995), our data suggest that their predation rate was not sufficient to suppress nauplii population growth.

\section{Bottom-up versus top-down controls on plankton community structure}

An additional goal of our research was to address the issues of bottom-up vs. top-down controls on plankton community structure in tropical waters. Nutrient addition by a major storm-runoff event in December 2003 resulted in a significant increase in phytoplankton and zooplankton biomass in southern Kaneohe Bay. The major finding of this study, however, is the negative trophic-cascade relationship which appears in the increasing biomass of carnivorous zooplankton, the decreasing biomass of omnivorous zooplankton, the increasing trends in chl $a$ and the diatom-indicator fucoxanthin, and the residual pools of unutilized macronutrients in the aftermath of the initial bloom. Increased zooplankton biomass was primarily due to a short-lived increase in the appendicularian population, and a more gradual increase in larger gelatinous predators. Dominant copepods remained at levels more typical of their long-term abundances in the bay, although the increased relative abundance of nauplii suggests that their secondary production was stimulated by enhanced food availability. Appendicularians were sufficiently abundant to clear a large fraction of the water column daily, but their selective grazing impact only helps to maintain a tight control on smaller, non-diatom phytoplankton. Assuming that copepods were the dominant diatom grazers, diatoms appear to have benefited almost exclusively by predator suppression of the copepod assemblage. The initial community response to nutrient input in Kaneohe Bay was a classic bottom-up stimulation of phytoplankton, grazers and predators. Nonetheless, over the course of $2 \mathrm{wk}$, top-down effects played an equally important role in the observed dynamics of phytoplankton and grazer populations.

The paradigm that resource limitation is of paramount importance in marine environments has shifted over the past 2 decades to include meso- and microzooplankton predation as substantial forces governing plankton community structure and dynamics in both temperate and tropical waters (e.g. Banse 1995, Verity \& Smetacek 1996, Calbet \& Landry 1999). It has also become apparent that the degree to which pelagic systems are influenced by resource availability and predation varies substantially over time and space (Kiørboe 1998). The results of our study suggest that systems can experience both bottom-up and top-down controls on their dynamics on different time scales following a nutrient-perturbation event, and thus provides additional evidence in support of the importance of both predator and resource limitation in governing the flow of energy through marine ecosystems.

\section{CONCLUSIONS}

Perturbations are common in planktonic systems, but sampling is generally too crude to reveal the details of complex community interactions. This is particularly true in tropical systems, where plankton response times are much shorter than in better-studied temperate and boreal waters. Major, multi-level community responses occur in the Kaneohe Bay ecosystem on time scales of a day to a week. Tropical zooplankton are therefore not only more tightly coupled to meteorological and physical forcing events than their temperate counterparts, particularly compared to spring-bloom events, but also time scales are sufficiently rapid for initial bottom-up surges in community response to generate meaningful top-down feedbacks in the form of trophic cascades.

Acknowledgements. We thank C. Allen and D. Ordoñez for their assistance in the analysis of zooplankton samples, and $\mathrm{K}$. Fagan, C. Young and F. Farrell for their help with field sampling. We also thank S. Christensen for her assistance in the analysis of HPLC samples and D. Hashimoto for his assistance in the analysis of nutrient samples. We are grateful to 2 anonymous reviewers for their insightful comments on the original version of this manuscript. This work was funded in part by a grant/cooperative agreement from the National Oceanic and Atmospheric Administration project, which is sponsored by the University of Hawaii Sea Grant College Program, SOEST, under Institutional Grant No. NA16RG2254 from the NOAA Office of Sea Grant, Department of Commerce. The views expressed herein are those of the authors and do not necessarily reflect the views of NOAA or any of its subagencies. UNIHISEAGRANT- SC-04-18. Contribution No. 6971 from the School of Ocean and Earth Science and Technology, University of Hawaii at Manoa, Honolulu, Hawaii 96822, USA.

\section{LITERATURE CITED}

Alldredge AL (1976) Field behavior and adaptive strategies of appendicularians (Chordata: Tunicata). Mar Biol 38:29-39

Alldredge AL (1977) House morphology and mechanisms of feeding in the Oikopleuridae (Tunicata, Appendicularia). J Zool 18:175-188

Alldredge AL (1981) The impact of appendicularian grazing on natural food concentrations in situ. Limnol Oceanogr 26:247-257

Baier CT, Purcell JE (1997) Effects of sampling and preserva- 
tion on apparent feeding by chaetognaths. Mar Ecol Prog Ser 146:37-42

Båmstedt UB, Martinussen MB (1999) Bioenergetics of ephyra larvae of the scyphozoan jellyfish Aurelia aurita in relation to temperature and salinity. Mar Biol 135:89-98

Banse K (1995) Zooplankton: pivotal role in the control of ocean production. ICES J Mar Sci 52:265-277

Bathen KH (1968) A descriptive study of the physical oceanography of Kaneohe Bay, Oahu, Hawaii. Hawaii Inst Mar Biol Tech Rep 14:1-353

Bayne BL (1983) Physiological ecology of marine molluscan larvae. In: The Mollusca, Vol 3. Academic Press, London, p 299-343

Berdalet E (1992) Effects of turbulence on the marine dinoflagellate Gymnodinium nelsonii. J Phycol 28:267-272

Bidigare RR, Benitez-Nelson C, Leonard CL, Quay PD, Parsons ML, Foley DG, Seki MP (2004) Influence of a cyclonic eddy on microheterotroph biomass and carbon export in the lee of Hawaii. Geophys Res Lett 30:1318-1322

Bouillon J (1999) Hydromedusae. In: Boltovskoy D (ed) South Atlantic zooplankton. Backhuys, Leiden p 385-465

Bradford-Grieve JM, Markhaseva EL, Rocha CEF, Abiahy B (1999) Copepoda. In: Boltovskoy D (ed) South Atlantic zooplankton. Backhuys, Leiden p 869-1098

Bückmann A, Knapp H (1975) Taxonomic characteristics used for the distinction of species of Appendicularia. Mitt Hamb Zool Mus Inst 72:201-228

Calbet A, Landry MR (1999) Mesozooplankton influences on the microbial food web: direct and indirect trophic interactions in the oligotrophic open ocean. Limnol Oceanogr 44: 1370-1380

Calbet A, Landry MR, Scheinberg RD (2000) Copepod ingestion rates in a subtropical bay: specific responses to a midsummer increase in the nanoplankton standing stock. Mar Ecol Prog Ser 193:75-84

Casanova JP (1999) Chaetognatha. In: Boltovskoy D (ed) South Atlantic zooplankton. Backhuys, Leiden, p 13531374

Checkley DM (1980) The egg production of a marine planktonic copepod in relation to its food supply. Laboratory studies. Limnol Oceanogr 25:430-446

Colebrook JM (1979) Continuous plankton records: seasonal cycles of phytoplankton and copepods in the North Atlantic Ocean and North Sea. Mar Biol 51:23-32

DeCarlo EH, Hoover DJ, Young CW, Scheinberg RD, MacKenzie FT (in press) Impact of storm runoff from subtropical watersheds on coastal water quality and productivity. Appl Geochem

Fenaux R (1993) The classification of Appendicularia (Tunicata): history and current state. Mém Inst Océanogr 17: $1-123$

Fenaux R (1998) Life history of the Appendicularia. In: Bone Q (ed) The biology of pelagic tunicates, Oxford University Press, Oxford, p 105-124

Fernández D, López-Urrutia Á, Fernández A, Acuña JL, Harris R (2004) Retention efficiency of 0.2 to $6 \mu \mathrm{m}$ particles by the appendicularians Oikopleura dioica and Fritillaria borealis. Mar Ecol Prog Ser 266:89-101

Frost BW (1972) Effects of size and concentration of food particles on the feeding behavior of the marine planktonic copepod Calanus pacificus. Limnol Oceanogr 17:805-815

Hoover DJ (2002) Fluvial nitrogen and phosphorus in Hawaii: storm runoff, land use, and impacts on coastal waters. $\mathrm{PhD}$ dissertation, Department of Oceanography, University of Hawaii, Honolulu

Hopcroft RR, Roff JC, Bouman HA (1998a) Zooplankton growth rates: the larvaceans Appendicularia, Fritillaria and Oikopleura in tropical waters. J Plankton Res 20: 539-555

Hopcroft RR, Roff JC, Lombard D (1998b) Production of tropical copepods in Kingston Harbour, Jamaica: the importance of small species. Mar Biol 130:593-604

Huntley ME, Lopez MDG (1992) Temperature dependent production of marine copepods: a global synthesis. Am Nat 140:201-242

Jeffrey SW, Vesk M (1997) Introduction to marine phytoplankton and their pigment signatures. In: Jeffrey SW, Mantoura RFC, Wright SW (eds) Phytoplankton pigments in oceanography: guidelines to modern methods. UNESCO, Paris, p 37-84

Jeong HJ, Lee CW, Yih WH, Kim JS (1997) Fragilidium cf mexicanum, a thecate mixotrophic dinoflagellate which is prey for and a predator on co-occurring thecate heterotrophic dinoflagellate Protoperidinium cf. divergens. Mar Ecol Prog Ser 151:299-305

Jokiel PL, Hunter CL, Taguchi S, Watara IL (1993) Ecological impact of a fresh water "reef kill" in Kaneohe Bay, Oahu, Hawaii. Coral Reefs 12:177-184

Kiørboe T (1993) Turbulence, phytoplankton cell size and the structure of pelagic food webs. Adv Mar Biol 29:1-72

Kiørboe T (1998) Population regulation and role of mesozooplankton in shaping marine pelagic food webs. Hydrobiologia 363:13-27

Kiørboe T, Nielsen TG (1990) Effects of wind stress on vertical water column structure, phytoplankton growth, and productivity of planktonic copepods. In: Barnes M, Gibson RN (eds) Trophic interactions in the marine environment. Proc 24th Eur Mar Biol Symp, Aberdeen University Press, Aberdeen, p 28-40

Kimmerer WJ (1984) Selective predation and its impact on the prey of Sagitta enflata (Chaetognatha). Mar Ecol Prog Ser 15:55-62

Kinzie RA III, Mackenzie FT, Smith SV, Stimson J (2001) CISNet: linkages between a tropical watershed and reef ecosystem. Final project report to NOAA. University of Hawaii, Honolulu, HI

Landry MR, Haas LW, Fagerness VL (1984) Dynamics of microbial plankton communities: experiments in Kaneohe Bay, Hawaii. Mar Ecol Prog Ser 16:127-133

Landry MR, Ondrusek ME, Tanner SJ, Brown SL, Bidigare RR, Coale KH, Fitzwater S (2000a) Biological response to iron fertilization in the eastern equatorial Pacific (IronEx II). I. Microplankton community abundances and biomass. Mar Ecol Prog Ser 201:27-42

Landry MR, Constantinou J, Latasa M, Brown SL, Bidigare RR, Ondrusek ME (2000b) Biological response to iron fertilization in the eastern equatorial Pacific (IronEx II). III. Dynamics of phytoplankton growth and microzooplankton grazing. Mar Ecol Prog Ser 201:57-72

Laws EA, Allen CB (1996) Water quality in a subtropical embayment more than a decade after diversion of sewage discharge. Pac Sci 50:194-210

Laws EA, Redalje DG, Haas LW, Bienfang PK, Eppley RW, Harrison WG, Karl DM, Marra J (1984) High phytoplankton growth and production rates in oligotrophic Hawaiian coastal waters. Limnol Oceanogr 29:1161-1169

Letelier RM, Bidigare RR, Hebel DV, Ondrusek M, Winn CD, Karl DM (1993) Temporal variability of phytoplankton community structure based on pigment analysis. Limnol Oceanogr 38:1420-1437

Malej A, Mozetiã P, Malaãiã V, Turk V (1997) Response of summer phytoplankton to episodic meteorological events (Gulf of Trieste, Adriatic Sea). PSZN I: Mar Ecol 18: $273-288$ 
Margalef DR (1967) Some concepts relative to the organization of plankton. Oceanogr Mar Biol Annu Rev 5:257-289

Martin D, Pinedo S, Sardá R (1996) Grazing by meroplanktonic polychaete larvae may help to control nanoplankton in the NW Mediterranean littoral: in situ experimental evidence. Mar Ecol Prog Ser 143:239-246

Mills CE (1995) Medusae, siphonophores, and ctenophores as planktivorous predators in changing global ecosystems. ICES J Mar Sci 52:575-581

Moore DS, McCabe GP (1993) Introduction to the practice of statistics. WH Freeman, New York

Munk WH, Riley GA (1952) Absorption of nutrients by aquatic plants. J Mar Res 11:215-240

Newbury TK, Bartholomew EF (1976) Secondary production of microcopepods in the southern, eutrophic basin of Kaneohe Bay, O'ahu, Hawaiian Islands. Pac Sci 30: 373-384

Nielsen TG, Kiørboe T (1991) Effects of a storm event on the structure of the pelagic food web with special emphasis on planktonic ciliates. J Plankton Res 13:35-51

Onbé T (1999) Ctenopoda and Onychopoda (= Cladocera). In: Boltovskoy D (ed) South Atlantic zooplankton. Backhuys, Leiden p 797-814

Paffenhöffer GA (1993) On the ecology of marine cyclopoid copepods (Crustacea, Copepoda). J Plankton Res 15:37-55

Ringuet S, Mackenzie FT (2005) Controls on nutrient and phytoplankton dynamics during normal flow and storm runoff conditions, southern Kaneohe Bay, Hawaii. Estuaries 28:327-337

Rollwagen Bollens C, Landry MR (2000) Biological response to iron fertilization in the eastern equatorial Pacific (IronEx II). II. Mesozooplankton abundance, biomass, depth distribution and grazing. Mar Ecol Prog Ser 201:43-56

Roman MR, Dam HG, Gauzens AL, Urban-Rich J, Foley DG, Dickey TD (1995) Zooplankton variability on the equator at $140^{\circ} \mathrm{W}$ during the JGOFS EqPac study. Deep-Sea Res II 42:673-693

Roman MR, Dam HG, Le Borgne R, Zhang X (2002) Latitudinal comparisons of equatorial Pacific zooplankton. DeepSea Res II 49:2695-2711

Saenger PJ, Holmes N (1992) Physiological temperature tolerance, and behavioural differences between tropical and temperate organisms. In: Connel DW, Hawker DW (eds) Pollution in tropical aquatic systems. CRC Press, London, p 69-95

Sato R, Tanaka Y, Ishimaru T (2001) House production by Oikopleura dioica (Tunicata, Appendicularia) under laboratory conditions. J Plankton Res 23:415-423

Scheinberg RD (2004) Food web structure and trophic dynamics of a subtropical plankton community, with an

Editorial responsibility: Otto Kinne (Editor-in-Chief), Oldendorf/Luhe, Germany emphasis on appendicularians. PhD thesis, University of Hawaii, Honolulu

Scheinberg RD, Landry MR, Calbet C (2005) Grazing of two warm water appendicularian on the natural prey assemblage of a subtropical coastal ecosystem. Mar Ecol Prog Ser 294:201-212

Sellner KG, Sellner SG, Lacouture RV, Magnien RE (2001) Excessive nutrients select for dinoflagellates in the stratified Patapsco River estuary: Margalef reigns. Mar Ecol Prog Ser 220:93-102

Smith SV, Kimmerer WJ, Laws EA, Brock RE, Walsh TW (1981) Kaneohe Bay sewage diversion experiment: perspectives on ecosystem responses to nutritional perturbation. Pac Sci 35:279-395

Szyper JP (1976) The role of Sagitta enflata in the southern Kaneohe Bay ecosystem. PhD dissertation, Department of Oceanography, University of Hawaii, Honolulu

Taguchi S (1982) Seasonal study of fecal pellets and discarded houses of appendicularia in a subtropical inlet, Kaneohe Bay, Hawaii. Estuar Coast Shelf Sci 14:545-555

Thomas WH, Gibson CH (1990) Effects of small-scale turbulence on microalgae. J Phycol 28:267-272

Timonin AG (1969) The quantitative relationship between different trophic groups of plankton in frontal zones of the tropical ocean. Oceanology 9:686-694

Tomas CR (1997) Identifying marine phytoplankton. Academic Press, San Diego, CA

Turner JT, Tester PA, Ferguson RL (1988) The marine cladoceran Penilia avirostris and the "microbial loop" of pelagic food webs. Limnol Oceanogr 33:245-255

Turner JT, Hopcroft RR, Lincoln JA, Huestis CS, Tester PA, Roff JC (1998) Zooplankton feeding ecology: grazing by marine copepods and cladocerans upon phytoplankton and cyanobacteria from Kingston Harbour, Jamaica. PSZN I: Mar Ecol 19:195-208

UNESCO (1994) Protocols for the Joint Global Ocean Flux Study (JGOFS) core measurements. 29:119-124

Verity PG, Smetacek V (1996) Organism life cycles, predation, and the structure of marine pelagic ecosystems. Mar Ecol Prog Ser 130:277-293

Vinogradov ME, Voronina NM (1963) Quantitative distribution of plankton in the upper layers of the Pacific equatorial currents. Tr Inst Okeanol Akad Nauk SSR 71: 22-59

Wassmann P (1998) Retention versus export food chains: processes controlling sinking loss from marine pelagic systems. Hydrobiologia 363:29-57

Wrobel D, Mills C (1998) Pacific coast pelagic invertebrates: a guide to the common gelatinous animals. Sea Challengers, Monterey, CA

Submitted: July 27, 2005; Accepted: November 28, 2005 Proofs received from author(s): July 11, 2006 